\title{
IAMJ
}

INTERNATIONAL

AYURVEDIC

MEDICAL JOURNAL

do) $\odot$ (.

Research Article

ISSN: 2320-5091

Impact Factor: 6.719

\section{AN OBSERVATIONAL CLINICAL STUDY TO EVALUATE SHIROROGA NIDANA IN CEREBROVASCULAR ACCIDENT}

\author{
$\underline{\text { Lavanya V K }}{ }^{1}$, Arun Kumar $\mathbf{M}^{2}$, Nagaraj $\underline{S}^{3}$
}

${ }^{1}$ Post Graduate Scholar, Department of PG Studies in Roganidana and Vikrutivigyana, Sri Dharmasthala Manjunatheshwara College of Ayurveda, Kuthpady, Udupi, PIN-574118, Karnataka, India

${ }^{2}$ Assistant Professor and Co-Guide, Department of PG Studies in Roganidana and Vikruthivigyana, Sri Dharmasthala Manjunatheshwara College of Ayurveda, Kuthpady, Udupi, PIN-574118, Karnataka, India

${ }^{3}$ Professor, Guide and HOD, Department of PG Studies in Roganidana and Vikruthivigyana, Sri Dharmasthala Manjunatheshwara College of Ayurveda, Kuthpady, Udupi, PIN-574118, Karnataka, India

\section{Corresponding Author: drlavanyavk@gmail.com}

\section{https://doi.org/10.46607/iamj0809072021}

(Published Online: July 2021)

Open Access

(c) International Ayurvedic Medical Journal, India 2021

Article Received: 24/06//2021 - Peer Reviewed: 25/06/2021 - Accepted for Publication: 25/06/2021

\section{Check for updates}

\begin{abstract}
Shiroroga is a broad term encompassing various diseases of the head involving Rakta Dushti due to vitiated Doshas. ${ }^{[1]}$ resulting in different neurovascular presentations, which is comparable with the vascular pathology of stroke. Cerebrovascular diseases include some of the most devastating disorders such as ischemic stroke and haemorrhagic stroke, which result in episodes of brain dysfunction. ${ }^{[2]}$ Currently, the stroke incidence in India is much higher and prevention of stroke is the best option, through control and/or avoiding risk factors such as hypertension. Objective: This calls for an evaluation of the possible Shiroroga Nidana in the development of Cerebro Vascular Accident (CVA) to identify more risk factors. Methods: In this cross-sectional observational study, 30 subjects diagnosed with the cerebrovascular accident were selected. The probable incidence of Nidana (causes), in patients, were assessed through a questionnaire developed for the study. The recorded data were analysed with descriptive statistics. Results: Nidana, like Vegadharana and Rodana causes Rakta Dushti along with Vata Prakopa. Aharaja Nidanas of Shiroroga are similar to that of Rakta Dushti Nidana and directly causes Dhatu Pradooshana in the body. Manasika Nidana or anxiety and emotional stress acts as Vyanjaka or Preraka
\end{abstract}


Hetu in Samprapti of Shiroroga. Conclusion: Bahya Hetu (external factors) triggers Dosha Kopa or causes Dhatu Pradooshana. In CVA patients, Vata Pradhana Tridosha Kopa and Rakta were vitiated to initiate the disease manifestation.

Keywords: Cerebrovascular Accident; Nidana; Shiras; Shiroroga; Stroke.

\section{INTRODUCTION}

Shiroroga (the diseases affecting the head) are described elaborately because the Shiras (head) being the seat of the brain controls the Omni-controller Prana Vayu (vitality). Acharya Charaka put forth the concept of Trimarma (three vital parts). ${ }^{[3]} \mathrm{He}$ considered Shiras, Hrudaya (heart), Basti (urinary system) as Marma- the most important vital parts or the root of Shareera (body). ${ }^{[4]}$ He explained clinical manifestations due to Dosha Abhighata (injury due to internal causes) where all three Dosha (regulatory factors of the body) are involved. ${ }^{[5]}$ The Dosha Abhighata Lakshanas (clinical features) of Shiras present various neurological emergencies. Acharya Charaka begins Rogachatushka with the description of Shiroroga, one among which is Ardita, the description of which closely resembles the clinical features of CVA. Stroke is the second leading cause of death worldwide, and the most common cause of severe physical disability. ${ }^{[6]}$ A stroke, or cerebrovascular accident, is defined as an abrupt onset of a neurologic deficit that is attributable to a focal vascular cause. ${ }^{[7]}$. This present era is going through significant changes in entire thinking patterns about the problems of health in human beings. All combined efforts are for maintaining health in the community and prevent the incidence of disease. Ayurveda also gives importance to the concept of maintaining health or prevention diseases. Stroke is preventable to a large extent as many of the risk factors for stroke are modifiable like high blood pressure, smoking, obesity, lack of physical activity and unhealthy diets. All these indicate the urgent need for better identification and understanding of risk factors to improve both primary and secondary prevention. ${ }^{[8]}$ This calls for an evaluation of the possible Shiroroga Nidana in the development of CVA for the identification of more risk factors or causes.

\section{Aim \& Objectives}

The present study clinically assesses Shiroroga Nidana in patients with cerebrovascular accidents.

\section{Materials \& Methods}

\section{Source of Data}

30 patients diagnosed with Cerebro Vascular Accident attending OPD \& IPD of Sri Dharmasthala Manjunatheswara Ayurveda Hospital, Udupi were selected for the study.

\section{Study Design}

It was an observational study on 30 patients diagnosed with a Cerebrovascular accident, using the diagnostic parameters. A detailed history about their regular food habits and daily regimen was taken to assess the probable incidence of Nidana and the recorded data were analysed with descriptive statistics.

\section{Inclusion Criteria}

1.Diagnosed cases of CVA.

2. Patients of either gender will be taken.

3. Patients aged above 20 years.

\section{Exclusion Criteria}

1. Intracranial space-occupying lesions

2. Cases of head injury

3. Cases with metabolic errors due to hepatic or renal disorders.

\section{Assessment Criteria}

- Assessment of Shiroroga Nidana in patients of cerebrovascular accident was done using a questionnaire developed for the study.

- The frequency of each Nidana was assessed through a Likert-type scale. 
Table 1: Likert Like Scale

\begin{tabular}{|l|l|l|}
\hline Frequency & Likert like scale & No of days/week \\
\hline Always & In about $90 \%$ and above of chances I could have & $6-7$ days in a week \\
\hline Often & Frequently about 70\% of chances I would have & $5-6$ days in a week \\
\hline Sometimes & $50 \%$ and above chance I would have used & $2-4$ days in a week \\
\hline Rarely & $10 \%$ and above chance I would have & 1 or 2 days a week \\
\hline Never & $0 \%$ chance & Not more than one day a week \\
\hline
\end{tabular}

- Always and often were considered as Ati Sevana of Nidana

\section{RESULTS}

The observations and results obtained after the evaluation of Shiroroga Nidana in CVA patients are as follows.

Table 2: Aharaja Nidana of Shiroroga in CVA patients

\begin{tabular}{|l|l|l|l|l|l|}
\hline Aharaja Nidana & Always & Often & Sometimes & Rarely & Never \\
\hline Guru Ahara & $0 \%$ & $36.7 \%$ & $16.7 \%$ & $23.3 \%$ & $23.3 \%$ \\
\hline Amla Ahara & $6.7 \%$ & $33.3 \%$ & $16.7 \%$ & $23.3 \%$ & $20 \%$ \\
\hline Harita Shaka & $33.3 \%$ & $53.3 \%$ & $6.7 \%$ & $6.7 \%$ & $0 \%$ \\
\hline Sheetambu & $43.3 \%$ & $26.7 \%$ & $20 \%$ & $0 \%$ & $10 \%$ \\
\hline Atyambu & $33.3 \%$ & $16.7 \%$ & $26.7 \%$ & $3.3 \%$ & $20 \%$ \\
\hline Madyapaana & $13.3 \%$ & $13.3 \%$ & $6.7 \%$ & $0 \%$ & $66.7 \%$ \\
\hline
\end{tabular}

Table 3: Viharaja Nidana of Shiroroga in CVA patients

\begin{tabular}{|l|l|l|l|l|l|}
\hline Viharaja Nidana & Always & Often & Sometimes & Rarely & Never \\
\hline Vegadharana & $0 \%$ & $3.3 \%$ & $40 \%$ & $33.3 \%$ & $23.3 \%$ \\
\hline Rodana (crying) & $0 \%$ & $3.3 \%$ & $33.3 \%$ & $10 \%$ & $53.3 \%$ \\
\hline Diwaswapna & $60 \%$ & $0 \%$ & $10 \%$ & $3.3 \%$ & $26.7 \%$ \\
\hline Ratri Jagarana & $13.3 \%$ & $0 \%$ & $13.3 \%$ & $3.3 \%$ & $70 \%$ \\
\hline Uchair Bhashya & $33.3 \%$ & $20 \%$ & $20 \%$ & $3.3 \%$ & $23.3 \%$ \\
\hline Utsweda & $40 \%$ & $16.7 \%$ & $16.7 \%$ & $3.3 \%$ & $23.3 \%$ \\
\hline Adha Pratatekshana & $40 \%$ & $33.3 \%$ & $6.7 \%$ & $0 \%$ & $20 \%$ \\
\hline
\end{tabular}

Table 4: Manasika Nidana of Shiroroga in CVA patients

\begin{tabular}{|l|l|l|l|l|l|}
\hline Manasika Nidana & Always & Often & Sometimes & Rarely & Never \\
\hline Shoka & $26.7 \%$ & $36.7 \%$ & $10 \%$ & $0 \%$ & $26.7 \%$ \\
\hline Krodham & $20 \%$ & $30 \%$ & $20 \%$ & $0 \%$ & $30 \%$ \\
\hline Chinta & $36.7 \%$ & $23.3 \%$ & $23.3 \%$ & $6.7 \%$ & $10 \%$ \\
\hline Bhayam & $16.7 \%$ & $13.3 \%$ & $3.3 \%$ & $3.3 \%$ & $63.3 \%$ \\
\hline
\end{tabular}

Table 5: Other Nidana related to the climate of Shiroroga in CVA patients

\begin{tabular}{|l|l|l|l|l|l|}
\hline Other Nidana & Always & Often & Sometimes & Rarely & Never \\
\hline Avashyaya /cold exposure & $16.7 \%$ & $36.7 \%$ & $20 \%$ & $20 \%$ & $6.7 \%$ \\
\hline Pragvata & $20 \%$ & $20 \%$ & $43.3 \%$ & $13.3 \%$ & $3.3 \%$ \\
\hline Dhooma /exposure to smoke & $60 \%$ & $20 \%$ & $20 \%$ & $0 \%$ & $0 \%$ \\
\hline Asatmya Gandha & $16.7 \%$ & $30 \%$ & $30 \%$ & $10 \%$ & $13.3 \%$ \\
\hline Rajas/dust & $40 \%$ & $46.7 \%$ & $10 \%$ & $3.3 \%$ & $0 \%$ \\
\hline Atapa /sunlight & $36.7 \%$ & $26.7 \%$ & $20 \%$ & $16.7 \%$ & $0 \%$ \\
\hline
\end{tabular}




\section{DISCUSSION}

The Nidana can be understood as Bahya and Abhyantara Hetu. Bahya Hetu are Aharaja, Viharaja, Manasika Nidanas which causes Dosha Dushti. Abhyantara Hetu is Dosha and Dooshya involved in the disease.

\section{Ahara}

Guru, Amla and Harita Shaka are described as Nidana of Shiroroga. Ahara is having 6 Rasa, 20 types of Guna, 2 Veerya, 3 types of Vipaka, various Karma and Prabhava. The mode of action is sometimes unpredictable for Dravya due to numerous influencing factors. But Ahara is taken daily and continuous use of any food as Ahara will cause Dosha Chaya and act as Viprakrushta Hetu for Vyadhi manifestations.

Guru, Amla, Harita Ahara directly cause Vyadhi Utpatti and act as Vyadhi Hetu. Mechanism of action is by Rakta Dhatu Dushti. These act as Dhatu Pradooshana Dravya.

\section{Jala (excess use of water / cold water)}

It can be both Sheetambu (cold water) or Atyambu (excess drinking of water). Always and often are considered as Atiyoga of Nidana Seva.

Sheetambu precipitates Vata Kopa and affects Shiras. Our body responds to a cold environment either outside or inside through hypothalamic regulation.

Atyambu is excess of Ambu Dhatu or Ati Dushti of Ambu Dhatu. Atyambu causes Rasa-Raktadi Dhatu Dushti by Kapha alone or Kapha -Pitta Kopa. Both Sheetambu and Atyambu acts as Doshabala Pravrutta Nidana.

\section{Madyapaana}

Madya directly affects Ojus in Hrudaya as well as leads to Rakta Dushti in Dasha Dhamani causing Shiroroga. Varuni type of Madya will directly cause Medo Vaha Sroto Dushti and Dushta Medus which is Abhadha form move in Rasa-Rakta Marga causing Dhamani Pratichaya and Margavarana Janya Pakshaghata. Due to a fewer number of subjects, Madyapana as a Nidana is not established in the study.

\section{Vegadharana}

Vegadharana causes Vata Prakopa and these all produce Shiroroga by acting as Viprakrushta Nidana (distant cause). Specifically, Ashru and Kshavathu
Vegadharana cause Prana Vata Dushti, while Mootra, Mala causes Apana Vata Dushti. Avarodha by Apana leads to Dushti of other Vata Dosha. Vegadharana acts as Dosha Hetu.

\section{Rodana (crying)}

Atiyoga of Rodana (crying) is Udeerana of Ashru. It also causes Vata Kopa and affects Indriya (sense organ of vision) directly leading to Shiroroga. Excess stress or mental tensions will cause emotional breakdown and most persons express it through crying. Such stress gives strain to the heart, increases blood pressure and sugar levels. Rodanat may be considered as Viprakrishta Nidana in CVA.

\section{Diwaswapna and Ratri Jagarana}

Diwaswapna causes Tridosha Dushti and Ratrijagarana cause Vata-Pitta Dushti. Atiyoga of Diwaswapna was observed more than Ratrijagarana in study subjects. Diwaswapna increases Snigdha Guna and is said to be Abhishyandi in Charaka Samhita. It does Lepana in Srotases which carry Rasa Raktadi Dhatus from Hrudaya due to Abhishyandana. Diwaswapna act as Viprakrushta Nidana in Shiroroga.

\section{Ucchair Bhashya (Loud Speaking)}

In loud speaking, there is excessive use of sound, increases blood pressure and increased consumption of energy. Vak Pravrutti is mainly controlled by Udana Vata. Atiyoga or Mithya Yoga of Vak Pravrutti causes Rasa Rakta Dhatu Kshaya and Udana Vata Kopa and produce disease. It is included under Asatmya Indriyartha Samyoga.

Utsweda (excess sweating): Utsweda is Urdhwa Sweda (excess sweating). It is seen in different diseases. Utsweda is indirectly related to stroke causation by triggering risk factors. For example, excess sweating may be due to diabetic hypoglycemia. It causes the ischemic effect on the brain and leads to stroke mimics.

It rather acts as Preraka Hetu in Shiroroga, and the majority of patients had repeated episodes of Utsweda. Adha Pratatekshana: Adha Pratatekshana resembles a stooped neck posture. In the study, Atiyoga of Adha Pratatekshana was noticed in patients either by mobile usage or continuous sitting and standing in stooped 
neck posture. Such wrong postures put pressure on vertebral arteries supplying the head and cause CVA. These type of causes acts as Vyanjaka / Preraka Nidana (triggering factors) for CVA.

Manasika Nidana: All mental stress causes raised blood pressure which triggers the manifestation of stroke. Many studies proved patients were under emotional stress on previous days of onset.

Manasika Nidanas in Ayurveda were categorised into that causes Pitta Prakopa and Vata Prakopa. Krodham or anger causes Pitta Prakopa and directly vitiates Rakta Dushti and causes Shiroroga.

Shoka (depression), Chinta (tension), and Bhayam (fear) all causes Vata Prakopa and lead to Shiroroga. Manasika Nidanas acts as Dosha Hetu.

Avashyaya (Cold Exposure): Cold exposure causes Vata Prakopa by Guna Samanya. In extreme cold, there will be alteration inflow of blood due to vasoconstriction which all trigger Rakta Dushti and causes Shiroroga.

Pragvata (Exposure to Wind): Exposure to cold winds cause causes cold stress which triggers vasoconstriction and strain the heart. To maintain circulation, bloop pressure and heart rate increase. A sudden rise in blood pressure with outdoor exertion can cause a stroke. Pragvata acts as Preraka Nidana (triggering factor) for CVA.

\section{Dhooma (any kind of smoke)}

All patients had exposure to Dhooma, with Atiyoga in the majority of individuals and Dhooma exposure also causes Indriya and Rakta Dushti. Sense organs are in close contact with the external environment and slight changes also cause disease.

Asatmya Gandha (bad or noxious odours): Exposure to bad smell or noxious odours trigger vomiting centres in the brain. Such repeated stimulation could have bad effects on the nervous system and causes Shiroroga. But the association is not established in CVA.

Rajas (dust): In the study, there was exposure to dust in all 30 subjects with a varied frequency of exposure. Atiyoga of Nidana Seva was seen in $86.7 \%$ of subjects and establish its role as a causative factor.
Exposure to outdoor air pollution has been associated with an increased risk of stroke, Harmful air pollutants include gases and particulate matter (PM). Airborne $\mathrm{PM}$ which is less than $10 \mu \mathrm{m}$ in aerodynamic diameter (PM10) can penetrate the airways and thus have the most adverse health effects.

Several epidemiological studies have found both short as well as long-term associations with ischemic stroke, although associations with hemorrhagic stroke are less consistent. ${ }^{[9]}$

Atapa (Sunlight): The majority of subjects had exposure to Atapa daily for labourers and such persons who work outside. Hemorrhagic strokes were believed to have onset after vigorous activity like such occupations. It vitiates Pitta and causes Rakta Dushti for the manifestation of disease. Atapa acts as Preraka Hetu.

\section{Discussion on the involvement of Dosha\& Dhatu}

Though there is a description of Tridoshas in Shiroroga Samprapti, Vata involvement was noted more in the study. This may be because all 5 subtypes of Vata Dosha take up the nervous system functions including the control motor and sensory activities more than other Doshas. A small per cent of Tridosha involvement was also observed and further study with a larger sample size is needed to check the involvement of Tridoshas There is the direct involvement of Rakta Dhatu in Samprapti and being the Drava Roopa Dhatu Rasa and Rakta moves together. These channels which carry Rasa and Rakta Dhatu are protected by Mamsadhara Kala and any injury will affect the normal functioning of all three Dhatus. Mamsa and Medo Dhatu Kshaya are inferred from the clinical presentation of Shithila Sandhi, Soola and Bala Kshaya. Majja Dhatu forms the structure of Mastulunga and is directly involved in Samprapti.

\section{CONCLUSION}

To summarise, Bahya Hetu were predominantly Vata Prakopakara. Some observations showed the involvement of other Dosha vitiation and Rakta Dushti. Shiroroga Samprapti where Rakta Dhatu Dushti in Shiras explains both ischemic and hemorrhagic pathology of CVA. Understanding 
Stroke from the view of Pakshaghata as Vata vyadhi limits the knowledge of the involvement of other Doshas and vascular pathology in stroke. Clinical observation study concluded that there is a definite role of Shiroroga Nidana and Samprapti in the better understanding of CVA along with Pakshaghata or Vata Vyadhi Samprapti.

\section{REFERENCES}

1. Agnivesha, Charaka, Drdhabala, Charaka Samhita, edited by Vaidya Jadavji Trikamji Acharya Acharya, Sutra Sthana, 17/11, edition reprint, Varanasi: Chaukhambha Sanskrit Sansthan; 2017. p. 99.

2. Fauci A S, Kasper D L, Hauser S L, Longo D L, Jameson J L, Joseph Loscalzo et al. Harrison's Principles of Internal Medicine, 20th ed. New York: McGraw Hill Medical; 2018. p.3068, Pp - 3528.

3. Agnivesha, Charaka, Drdhabala, Charaka Samhita, edited by Vaidya Jadavji Trikamji Acharya, Siddhi Sthana, Trimarmeeyam Siddhi: Chapter 9, edition reprint, Varanasi: Chaukhambha Sanskrit Sansthan; 2017. p. 514.
4. Agnivesha, Charaka, Drdhabala, Charaka Samhita, edited by Vaidya Jadavji Trikamji Acharya, Siddhi Sthana, 9/3, edition reprint, Varanasi: Chaukhambha Sanskrit Sansthan; 2017. p. 716.

5. Agnivesha, Charaka, Drdhabala, Charaka Samhita, edited by Vaidya Jadavji Trikamji Acharya, Siddhi Sthana, 9/6, edition reprint, Varanasi: Chaukhambha Sanskrit Sansthan; 2017. p. 717.

6. Ralston S H, Penman I D, Strachan M WJ, Hobson R $\mathrm{P}$, editors. Davidson's principles and practice of medicine, $23^{\text {rd }}$ ed. Sydney: Elsevier; 2018. p.1150, Pp $-1417$.

7. Fauci A S, Kasper D L, Hauser S L, Longo D L, Jameson J L, Joseph Loscalzo et al. Harrison's Principles of Internal Medicine, 20th ed. New York: McGraw Hill Medical; 2018. p.3068, Pp - 3528.

8. Seshadri. S, Debette. S, editors. Risk Factors for Cerebrovascular Disease and Stroke, 1st ed, New York: Oxford University Press; 2016. p. 13.

9. Wellenius GA, Schwartz J, Mittleman MA. Air pollution and hospital admissions for ischemic and hemorrhagic stroke among Medicare beneficiaries. Stroke. 2005; 36:2549-2553.

\section{Source of Support: Nil Conflict of Interest: None Declared}

How to cite this URL: Lavanya V K et al: An Observational Clinical Study To Evaluate Shiroroga Nidana In Cerebrovascular Accident. International Ayurvedic Medical Journal \{online\} 2021 \{cited July 2021\} Available from: http://www.iamj.in/posts/images/upload/1366_1371.pdf 